\title{
Replacement of heart valves with frame-mounted tissue grafts
}

\author{
MARIAN I. IONESCU, BROJESH C. PAKRASHI, \\ DAVID A. S. MARY, IVAN T. BARTEK, and \\ GEOFFREY H. WOOLER
}

Department of Cardiothoracic Surgery, The General Infirmary at Leeds and Leeds University

Ionescu, M. I., Pakrashi, B. C., Mary, D. A. S., Bartek, I. T., and Wooler, G. H. (1974). Thorax, 29, 56-67. Replacement of heart valves with frame-mounted tissue grafts. Between April 1969 and March 1973, 213 patients had heart valve replacement with frame-mounted autologous or homologous fascia lata or with heterologous pericardial grafts. There were 111 single aortic, 95 single mitral, and seven tricuspid valve replacements.

The incidence of hospital and late mortality was each $10 \%$ for the entire series and the main causes were myocardial failure and infective endocarditis.

The majority of patients obtained significant symptomatic improvement. In patients with aortic replacement there was a statistically significant reduction in cardiothoracic ratio and in the voltage of the electrocardiogram.

Regurgitant murmurs developed in $11.6 \%$ of aortic patients and in $51.6 \%$ after mitral replacement (in $37.5 \%$ the murmur has not increased in intensity while in $14.1 \%$ it has gradually progressed). None of these mitral patients requires reoperation. Grafts in the tricuspid position have not shown signs of dysfunction or failure. Graft failure has not occurred in the aortic replacement series. From the mitral position six grafts have been removed due to failure. All six were made of autologous fascia and all showed varying degrees of thickening and retraction of cusps. There were six episodes of peripheral embolization (five transient) and one left atrial thrombosis. All seven patients are alive. Anticoagulants were not used.

The results of haemodynamic studies and in vitro hydrodynamic experiments are discussed and an explanation for graft dysfunction in the mitral position is presented.

The actuarial analysis of this series of patients over a period of up to 54 months postoperatively has shown encouraging results.

Frame-supported tissue grafts have been used for heart valve replacement in this department since April 1969 (Ionescu and Ross, 1969; Ionescu, Ross, Deac, and Wooler, 1970a). The clinical and laboratory data which have accumulated over the past four and a half years justify an analysis of the results. This report describes the immediate and late results of patients with aortic, mitral, and tricuspid valve replacement.

\section{CLINICAL MATERIAL}

Between April 1969 and March 1973, 239 patients had heart valve replacement with 262 tissue grafts made of either autologous or homologous fascia lata or heterologous pericardium.

Reprint requests to: M. I. Ionescu, Department of Cardiothoracic Surgery, The General Infirmary at Leeds, Leeds 1.
Thirty-three patients in this series had multiple valve replacement, single tricuspid valve replacement, or unmounted grafts inserted in the aortic position.

This report will analyse those patients who had isolated aortic or mitral valve replacement and will briefly present the results of a small group of patients who had tricuspid valve replacement. In the single aortic valve replacement group there were 111 patients aged 13 to 69 years. Seventy-eight were males and 33 females. In the single mitral valve replacement group there were 95 patients aged 9 to 68 years. Forty-two were males and 53 females. Seven patients (4 men and 3 women) aged 29 to 48 years had tricuspid valve replacement either alone or in combination with other cardiac surgical procedures.

Details of preoperative heart valve lesions are given in Table I. At the time of heart valve replacement the majority of patients were in grade II and III, assessed according to the New York Heart Association (NYHA) classification. 
T A B L E I

VALVE LESIONS IN 213 PATIENTS

\begin{tabular}{|c|c|c|c|}
\hline $\begin{array}{l}\text { Predominant } \\
\text { Valve } \\
\text { Lesion }\end{array}$ & $\begin{array}{l}111 \text { Aortic } \\
78 \text { men, } \\
33 \text { women } \\
13-69 \text { yr old }\end{array}$ & $\begin{array}{l}95 \text { Mitral } \\
42 \text { men, } \\
53 \text { women } \\
9-68 \text { yr old }\end{array}$ & $\begin{array}{l}7 \text { Tricuspid } \\
4 \text { men, } \\
3 \text { women } \\
29-48 \text { yr old }\end{array}$ \\
\hline $\begin{array}{l}\text { Stenosis } \\
\text { Regurgitation } \\
\text { Mixed disease } \\
\text { Congenital } \\
\text { Malfunction of } \\
\text { previously } \\
\text { replaced valves }\end{array}$ & $\begin{array}{r}35 \\
30 \\
40 \\
6\end{array}$ & $\begin{array}{r}3 \\
11 \\
75 \\
1 \\
5\end{array}$ & $\begin{array}{l}\overrightarrow{6} \\
1 \\
-\end{array}$ \\
\hline
\end{tabular}

At the time of aortic valve replacement 40 patients had concomitant operative procedures for associated cardiac or coronary artery lesions, 15 of them involving open surgery of the mitral valve. Six patients had previous aortic valve replacement. In the mitral replacement group 38 patients had one or two previously performed closed mitral valvotomies and five patients had previous mitral valve replacement. Twenty-five patients had other cardiac abnormalities in addition to the mitral valve lesion.

TYPE OF VALVE GRAFTS USED Three basically similar types of tissue grafts were used in this series. The three cusp valve grafts were made of biological tissue attached to Dacron-covered titanium frames ${ }^{1}$ (Ionescu et al., 1970b; Ionescu et al., 1972; Bartek, Holden, and Ionescu, 1974). Valves prepared from the patient's own fascia lata at the time of surgery, under sterile conditions, were used in 80 cases ( 25 in the aortic, 52 in the mitral, and 3 in the tricuspid position). Preserved homologous fascia lata was used in 65 patients $(44$ in the aortic, 20 in the mitral, and one in the tricuspid position). Sixty-eight patients (42 with aortic, 23 with mitral, and 3 with tricuspid replacement) had valves made of preserved heterologous pericardium ${ }^{2}$.

The homologous fascia lata valves were sterilized and preserved in either $0.2 \%$ buffered glutaraldehyde (Reis et al., 1971) or $4 \%$ buffered formaldehyde (Moeys, Mreyen, and den Hartog, 1954). The heterologous pericardial valves were either treated with

\section{T A B L E I I}

TYPE OF TISSUE VALVES AND PERIOD OF TIME OF THEIR CLINICAL USE

\begin{tabular}{l|l|ccc|c}
\hline \multicolumn{1}{c|}{ Type of Valve Graft } & Period of Time & A & M & T & Total \\
\hline Autologous fascia lata & $\begin{array}{l}\text { April 1969- } \\
\text { September 1970 }\end{array}$ & 25 & 52 & 3 & 80 \\
Homologous fascia lata & June 1970- \\
Heterologous pericardium & $\begin{array}{l}\text { February 1971 } \\
\text { March 1971- } \\
\text { March 1973 }\end{array}$ & 42 & 20 & 1 & 65 \\
\hline Total & 42 & 3 & 68 \\
\hline
\end{tabular}

1 Six homologous fascia lata valves had been used in April and May 1969.

$\mathbf{A}=$ Single aortic valve replacement

$\mathbf{M}=$ Single mitral valve replacement

$T=$ Tricuspid valve replacement single or in combination with other cardiac surgical procedures

1Hypodermic Services, 1 Headlands Road, Liversedge, Yorkshire. 2 Calf pericardium was used throughout this series.
$0.2 \%$ buffered glutaraldehyde or given the complex chemical treatment described by Carpentier and Dubost (1972).

These valves were used during successive periods of time, as shown in Table II.

Valve graft sizes varied from 16 to $24 \mathrm{~mm}$ diameter for aortic replacement (the majority of patients have received $20 \mathrm{~mm}$ size grafts). For mitral or tricuspid replacement the grafts used had an internal diameter of 22 to $30 \mathrm{~mm}$ (the most commonly used grafts had 24 and $26 \mathrm{~mm}$ diameter).

\section{RESULTS}

HOSPITAL AND LATE MORTALITY There were eight hospital deaths in patients with aortic valve replacement and 15 in patients with mitral replacement. Ten patients with aortic replacement and nine with mitral replacement died 2 to 33 months postoperatively. The main causes of hospital and late mortality were myocardial failure and infective endocarditis in both aortic and mitral groups. None of the deaths occurred as a direct result of valve graft failure (Table III).

T A B L E I I I

MORTALITY IN PATIENTS WITH SINGLE AORTIC OR MITRAL VALVE REPLACEMENT

\begin{tabular}{|c|c|c|c|c|c|c|}
\hline \multirow{2}{*}{$\begin{array}{c}\text { Cause of } \\
\text { Death }\end{array}$} & \multicolumn{2}{|c|}{$\begin{array}{l}111 \text { Aortic } \\
\text { Replacements }\end{array}$} & \multicolumn{2}{|c|}{$\begin{array}{c}95 \text { Mitral } \\
\text { Replacements }\end{array}$} & \multicolumn{2}{|c|}{ Total } \\
\hline & $\begin{array}{l}\text { Hospital } \\
\text { Death }\end{array}$ & $\begin{array}{c}\text { Late } \\
\text { Death }\end{array}$ & $\begin{array}{c}\text { Hospital } \\
\text { Death }\end{array}$ & $\begin{array}{c}\text { Late } \\
\text { Death }\end{array}$ & Aortic & Mitral \\
\hline $\begin{array}{l}\text { Myocardial } \\
\text { failure }\end{array}$ & 3 & 2 & 6 & 3 & 5 & 9 \\
\hline $\begin{array}{l}\text { Infective } \\
\text { endocarditis }\end{array}$ & 2 & 3 & 2 & 4 & 5 & 6 \\
\hline $\begin{array}{l}\text { Arrhythmia } \\
\text { Respiratory }\end{array}$ & 二 & $\overline{1}$ & $\begin{array}{l}4 \\
1\end{array}$ & $\overline{1}$ & -1 & $\begin{array}{l}4 \\
2\end{array}$ \\
\hline $\begin{array}{l}\text { Sudden death } \\
\text { Cerebral } \\
\text { infarction }\end{array}$ & $\overline{2}$ & $\frac{3}{-}$ & $=$ & $=$ & $\begin{array}{l}3 \\
2\end{array}$ & $\overline{-}$ \\
\hline $\begin{array}{l}\text { Haemorrhage } \\
\text { Status }\end{array}$ & 二 & $=$ & 1 & 二 & 二 & 1 \\
\hline $\begin{array}{l}\text { Gangrene of } \\
\text { ileum }\end{array}$ & 1 & 1 & - & - & 2 & - \\
\hline $\begin{array}{l}\text { Ruptured } \\
\text { oesophagus }\end{array}$ & - & - & 一 & 1 & - & 1 \\
\hline Total & 8 & 10 & 15 & 9 & 18 & 24 \\
\hline
\end{tabular}

There have not been early or late deaths in patients with tricuspid valve replacement.

Actuarial representation of survival among 103 patients with aortic and 80 patients with mitral replacement who were discharged from hospital and followed for a period of up to four and a half years is shown in Figure 1.

Infective endocarditis occurred in both the aortic and the mitral series, and the incidence was similar. Contamination during the surgical period 


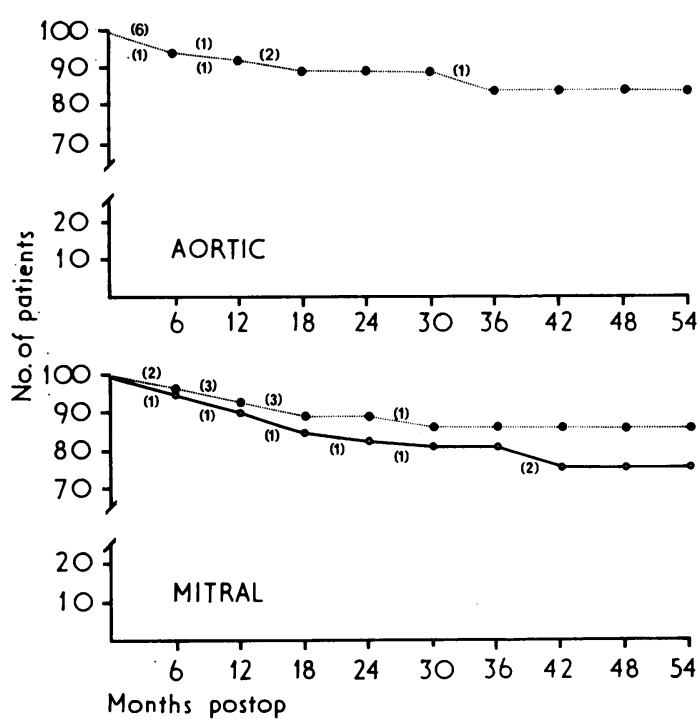

FIG. 1. Actuarial representation of survival rate of patients discharged from hospital and followed for a period of up to 54 months postoperatively. There were 103 patients with aortic and 80 patients with mitral valve replacement. In the mitral group the upper dotted line represents survival rate while the lower line depicts survivors with mitral tissue grafts.

could be incriminated in those patients in whom the infection became clinically evident in the first six postoperative months. Only three out of 14 infected patients survived, two of them after removal and replacement of the infected graft and one following antibiotic treatment alone (Table IV). Infective endocarditis has not been diagnosed in the tricuspid replacement series. An analysis of the occurrence of infective endocarditis over the years showed that the infection rate has considerably decreased over the last three years (Table V)
T A B LE V

YEARLY INCIDENCE OF INFECTIVE ENDOCARDITIS FOLLOWING ISOLATED AORTIC AND MITRAL VALVE
REPLACEMENT WITH TISSUE GRAFTS

\begin{tabular}{l|cccc}
\hline & \multicolumn{4}{|c}{ Year of Surgery } \\
\cline { 2 - 5 } $\begin{array}{c}\text { Aortic replacement } \\
111 \text { patients }\end{array}$ & 1969 & 1970 & 1971 & $1972 / 73$ \\
\hline $\begin{array}{l}\text { Mitral replacement } \\
95 \text { patients }\end{array}$ & $0 / 10$ & $5 / 28$ & $3 / 38$ & $0 / 35$ \\
\hline Total & $1 / 40$ & $2 / 29$ & $2 / 9$ & $1 / 17$ \\
\hline
\end{tabular}

since a rigorous system of microbiological monitoring was introduced together with a reduction in the duration of the prophylactic antibiotic therapy (Freeman, 1974; Freeman and King, 1972a and $b)$.

The incidence of thromboembolism has been very low although anticoagulants were not used. Two patients with aortic replacement have developed transient hemiparesis. In patients with mitral replacement there have been three episodes of peripheral embolization without sequelae, one hemiplegia, and one patient was found to have left atrial thrombus. There has not been any clinical evidence of thromboembolism in patients with tricuspid replacement.

Evidence of haemolysis This was specifically looked for in 35 patients with aortic replacement (7 with diastolic murmurs and 28 additional randomly selected cases). None of the patients showed clinical signs of haemolysis irrespective of the size of the valve graft. Laboratory evidence of haemolysis, however, was present in patients with aortic regurgitation (Dave et al., 1972).

Postoperative regurgitant murmurs Aortic diastolic murmurs developed in 12 of 103 patients

T A B L E I V

INFECTIVE ENDOCARDITIS FOLLOWING ISOLATED AORTIC AND MITRAL VALVE REPLACEMENT WITH TISSUE

\begin{tabular}{|c|c|c|c|c|c|c|c|c|c|c|}
\hline \multirow[b]{2}{*}{$\begin{array}{c}\text { Valve } \\
\text { at } \\
\text { Risk }\end{array}$} & \multirow[b]{2}{*}{$\begin{array}{l}\text { Time of } \\
\text { Occurrence } \\
\text { Postop. }\end{array}$} & \multirow{2}{*}{\multicolumn{2}{|c|}{ No. $(\%)$}} & \multicolumn{3}{|c|}{ Type of Graft } & \multicolumn{2}{|c|}{ Treatment } & \multicolumn{2}{|c|}{ Outcome } \\
\hline & & & & $\begin{array}{l}\text { Autologous } \\
\text { Fascia Lata }\end{array}$ & $\begin{array}{l}\text { Homologous } \\
\text { Fascia Lata }\end{array}$ & $\begin{array}{c}\text { Heterologous } \\
\text { Pericardium }\end{array}$ & Antibiotics & $\begin{array}{c}\text { Valve } \\
\text { Replacement }\end{array}$ & Dead & Alive \\
\hline \multirow[t]{3}{*}{ Aortic } & & & & 25 & 44 & 42 & & & & \\
\hline & $\begin{array}{l}<6 \mathrm{mth} \\
>6 \mathrm{mth}\end{array}$ & $\begin{array}{l}6 \\
2 \\
\end{array}$ & $\begin{array}{l}(5 \cdot 4) \\
(1 \cdot 8) \\
\end{array}$ & $\frac{3}{-}$ & $\begin{array}{l}3 \\
2\end{array}$ & $\overline{-}$ & $\begin{array}{l}4 \\
2 \\
\end{array}$ & 2 & $\begin{array}{l}4 \\
1\end{array}$ & $\begin{array}{l}2 \\
1\end{array}$ \\
\hline & Total & 8 & $(7 \cdot 2)$ & 3 & 5 & - & 6 & 2 & 5 & 3 \\
\hline \multirow[t]{3}{*}{$\overline{\text { Mitral }}$} & & & & 52 & 20 & 23 & & & & \\
\hline & $\begin{array}{l}<6 \mathrm{mth} \\
>6 \mathrm{mth}\end{array}$ & $\begin{array}{l}4 \\
2\end{array}$ & $\begin{array}{l}(4 \cdot 2) \\
(2 \cdot 1)\end{array}$ & 1 & 2 & 1 & 2 & 2 & $\begin{array}{l}4 \\
2\end{array}$ & $\overline{-}$ \\
\hline & Total & 6 & $\overline{(6 \cdot 3)}$ & 2 & 2 & 2 & 2 & 4 & 6 & - \\
\hline
\end{tabular}


$(11.6 \%)$ who survived the operation. The murmur appeared in the immediate postoperative period in three cases and between one and eight months after surgery in the remaining nine patients. Aortic root angiograms were performed in these 12 patients. Eight were found to have trivial (three of them due to perivalvular leaks), one mild, and three moderate aortic regurgitation according to the angiographic criteria of Brandt, Roche, BarrattBoyes, and Lowe (1969) (Fig. 2). Although the number of patients with postoperative aortic regurgitation is too small for correct statistical analysis, a higher incidence of aortic regurgitation

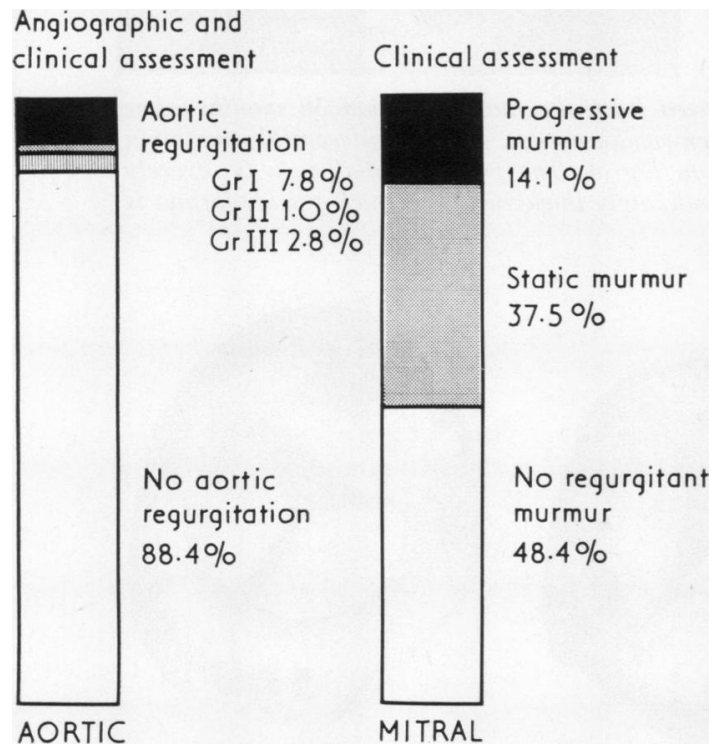

FIG. 2. Diagrammatic representation of patients with regurgitant murmurs followed for a period of 6 to 54 months postoperatively. In the aortic group the degree of regurgitation was assessed by clinical and angiographic criteria. In the mitral group only a few patients have had angiographic studies.
T A B LE VI

ANALYSIS OF POSSIBLE SIGNIFICANT FACTORS IN POST. OPERATIVE AORTIC REGURGITATION IN 103 OPERATIVE SURVIVORS

\begin{tabular}{|c|c|c|}
\hline Details & $\begin{array}{c}\text { With } \\
\text { Regurgitation } \\
\text { (12 Patients) }\end{array}$ & $\begin{array}{c}\text { No } \\
\text { Regurgitation } \\
\text { (91 Patients) }\end{array}$ \\
\hline $\begin{array}{l}\text { Malfunctioning previously } \\
\text { replaced valves } \\
\text { Valve calcification } \\
\text { Type of graft: } \\
\text { Autologous fascia lata } \\
\text { Homologous fascia lata } \\
\text { Heterologous pericardium } \\
\text { Suture to heart valve annulus: } \\
\text { Continuous } \\
\text { Interrupted }\end{array}$ & $\begin{array}{l}2 \\
7 \\
5 \\
5 \\
2 \\
3 \\
9\end{array}$ & $\begin{array}{r}4 \\
54 \\
17 \\
34 \\
40 \\
6 \\
85\end{array}$ \\
\hline
\end{tabular}

was noted in patients with previous aortic valve replacement and in those who received autologous fascia lata grafts (Table VI).

Mitral systolic murmurs developed in $51.6 \%$ of patients (Fig. 2). In all cases except one, the murmur appeared during the first 12 months postoperatively. Eight patients with murmurs had their grafts removed because of graft failure in six and graft dysfunction in two. In the remaining 33 cases with mitral systolic murmurs, the murmur has not increased in intensity in 24 patients while in nine it has gradually progressed. Angiographic studies in some of these patients have shown that not every systolic murmur is associated with mitral valve graft regurgitation.

On clinical criteria, all tissue valves in the tricuspid position are competent.

Graft failure and dysfunction There has not been any instance of valve graft failure in either the aortic or the tricuspid position. Two grafts have been removed from the aortic area, one eight months after implantation of a defectively prepared valve and the second one 37 months postoperatively. This second case developed infective endocarditis in the immediate postoperative period

T A B L E VII

MITRAL GRAFT FAILURE IN 80 OPERATIVE SURVIVORS

\begin{tabular}{|c|c|c|c|c|c|}
\hline No. & $\begin{array}{c}\text { Time of Appearance } \\
\text { of Regurgitant } \\
\text { Murmur } \\
\text { (months postop.) }\end{array}$ & $\begin{array}{l}\text { Time of Removal } \\
\text { of Failed Graft } \\
\text { (months postop.) }\end{array}$ & $\begin{array}{c}\text { Type of Subsequent Valve } \\
\text { Replacement }\end{array}$ & Outcome & Graft Pathology \\
\hline $\mathbf{1}$ & \multirow{4}{*}{$\begin{array}{c}\mathbf{3} \\
\text { Immediately } \\
\text { postop. } \\
\text { Immediately } \\
\text { postop. } \\
\mathbf{6}\end{array}$} & $\begin{array}{l}10 \\
17\end{array}$ & $\begin{array}{l}\text { Mitral Starr } \\
\text { Mitral and tricuspid Starr }\end{array}$ & $\begin{array}{l}\text { Well } \\
\text { Died }\end{array}$ & \multirow{4}{*}{$\begin{array}{l}\text { All grafts showed } \\
\text { retraction of one } \\
\text { cusp and slight } \\
\text { thickening of the } \\
\text { other two cusps. }\end{array}$} \\
\hline $\begin{array}{l}3 \\
4\end{array}$ & & $\begin{array}{l}20 \\
27\end{array}$ & $\begin{array}{l}\text { Mitral Starr } \\
\text { Mitral Starr }\end{array}$ & $\begin{array}{l}\text { Well } \\
\text { Well }\end{array}$ & \\
\hline 5 & & 36 & Mitral Starr & $\begin{array}{l}\text { Heart failure; } \\
\text { periprosthetic } \\
\text { leak }\end{array}$ & \\
\hline 6 & & 38 & Mitral Braunwald-Cutter & Well & \\
\hline
\end{tabular}

Died two years after mitral and tricuspid Starr valve replacement following oesophagectomy. 
(a)

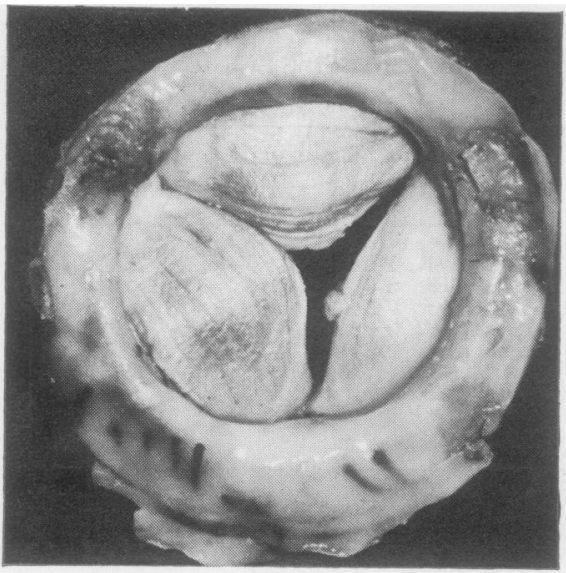

(b)

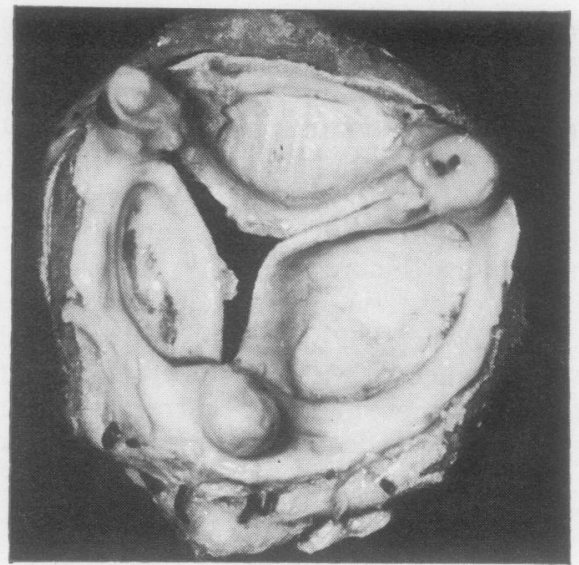

FIG. 3. Failed autologous fascia lata valve removed from the mitral position 36 months after insertion: (a) inflow or atrial aspect; (b) outflow or ventricular aspect. The circumferentialorientation of the cusps as regards the aortic root is shown in Fig. 4. The posteromedial cusp is severely retracted and thickened. The other two cusps are moderately thickened. The thick pseudo-intima is visible towards the commissures.

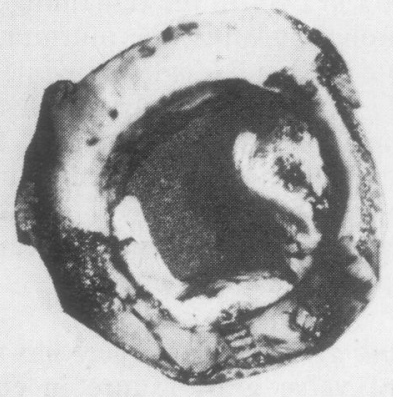

10

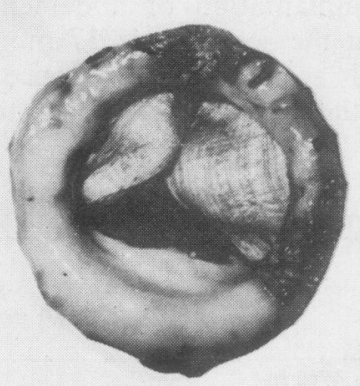

27

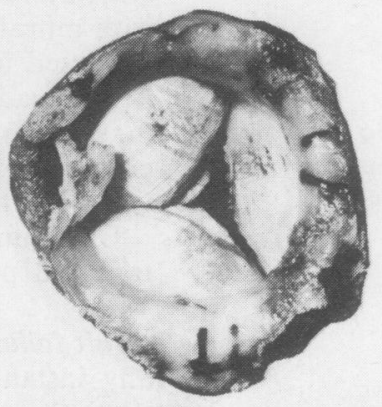

17

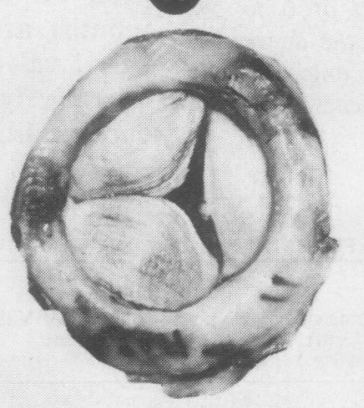

36

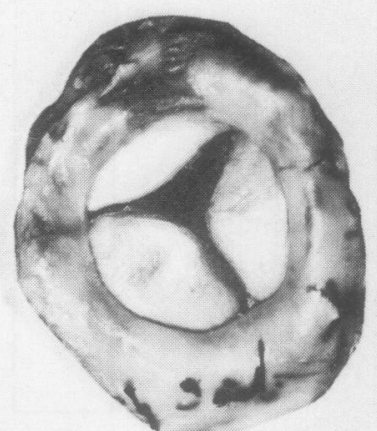

20.

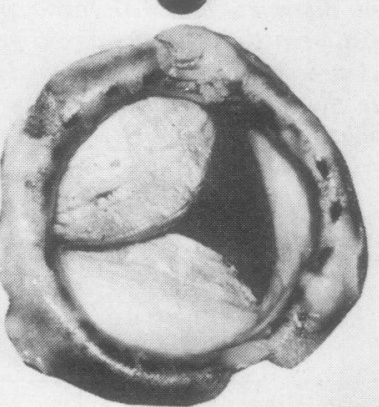

38

FIG. 4. The six autologous fascia lata valves removed from the mitral position due to graft failure are shown from their inflow aspect. All valves are depicted as they were positioned in the mitral annulus with the cusp facing the aortic root between 9 and 1 o'clock. The numbers represent the time in months after insertion when the failed grafts were removed. The valve removed 10 months postoperatively had only the cusp facing the aorta retracted. 
and was treated with antibiotics alone. The graft damaged by infection developed progressive regurgitation.

There have been six instances of graft failure in the mitral position (Table VII). Mitral systolic murmurs were heard in these cases in the first six postoperative months. The grafts were removed 10 to 38 months after implantation. All six patients survived reoperation and prosthetic mitral valve replacement. One of them died two years after reoperation following oesophagectomy.

All six grafts which were originally made of autologous fascia lata showed retraction and severe thickening of one cusp and slight to moderate thickening of the other cusps of the graft (Figs. 3a and b). There was no relationship between the severely retracted cusp and the circumferential position of that cusp as regards the left ventricular outlet (Fig. 4).

Two grafts with mechanical dysfunction due to faulty valve preparation were removed from the mitral position. One of them, which was removed six months after insertion, had a trivial central leak, while the second one removed 18 months postoperatively had acute disruption of a suture line and one cusp had become detached from the frame. Both these valves appeared macroscopically to be identical with freshly prepared valves. The cusps were thin and pliable and they retained the normal fascial striae. Both patients are well after reoperation and prosthetic valve replacement.

All the failed grafts removed from patients were fixed, sectioned, stained, and examined microscopically. The failed grafts examined showed a central, slightly fragmented band of necroticlooking connective tissue and a superficial narrow band of fibrous tissue along the surface of the central band. In the less retracted cusps the superficial band appeared viable and its fibres were thickened and hyaline. The thickening of the cusps can be accounted for by the formation of a thick hyaline fibrous sheath (Fig. 5). This sheath corresponds to the pseudo-intima described by Silver and Trimble (1972). It was clearly continuous with the host connective tissue, but whether organization has proceeded from the periphery or from the blood stream could not be determined from these sections.

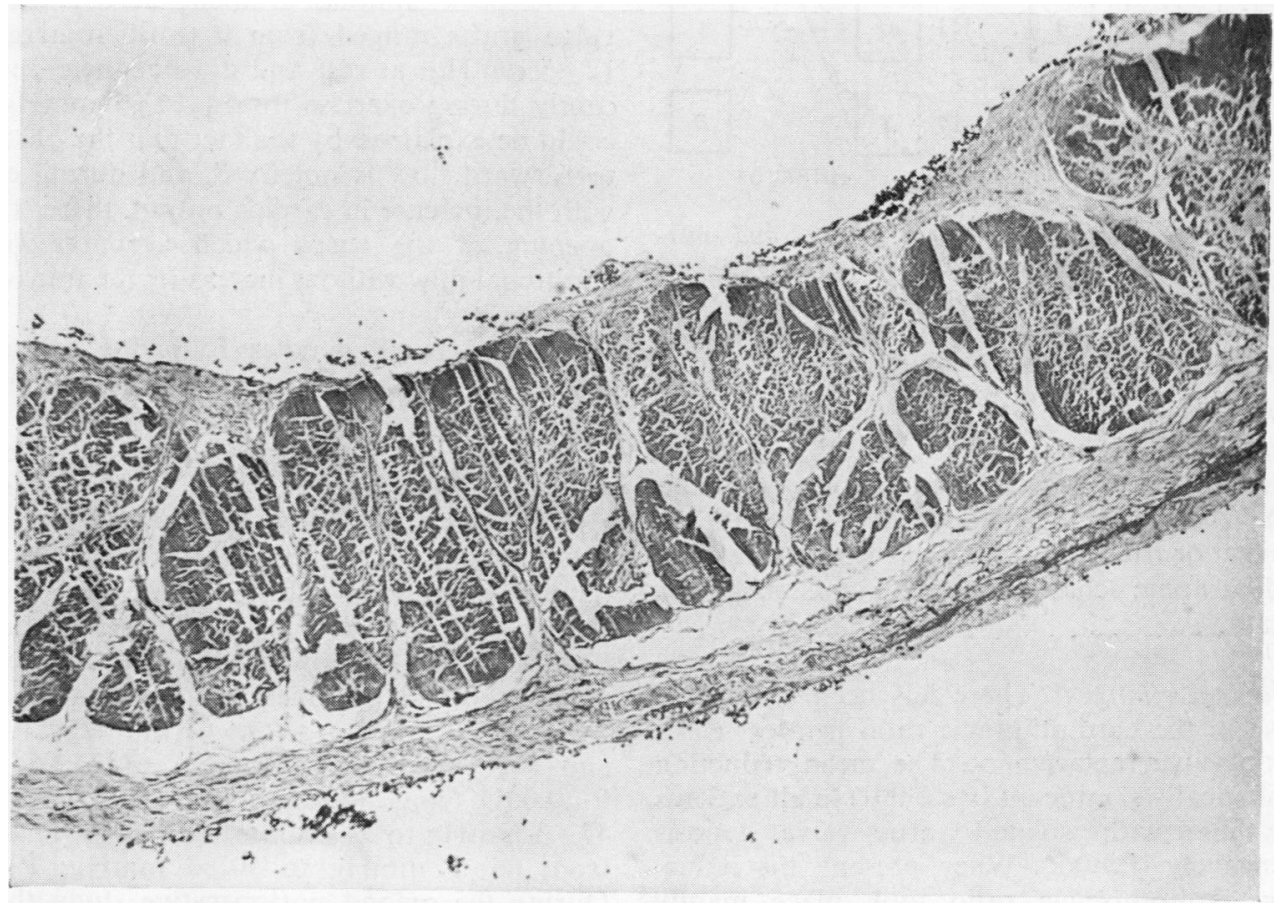

FIG. 5. Microscopic section through a moderately thickened cusp of an autologous fascia lata valve removed from the mitral position 10 months after insertion. The middle of the cusp shows the central band of altered connective tissue. The hyaline fibrous sheath appears on either side of the cusp. Haema-
toxylin and eosin. 
Clinical evaluation All patients who are alive and have been followed up for 6 to 54 months postoperatively were analysed. Each patient had clinical, electrocardiographic, and radiological examination. Haemodynamic and angiographic studies were performed in a limited number of cases.

Symptoms Pre- and postoperative effort tolerance with respect to dyspnoea was graded according to the NYHA classification and is presented diagrammatically in Figure 6. Preoperative grades refer to the clinical assessment just before operation. However, in some cases the grades minimize the true cardiac status because several patients, especially in the aortic group, gave a previous history of acute left ventricular failure and some of them had right-sided failure as well.
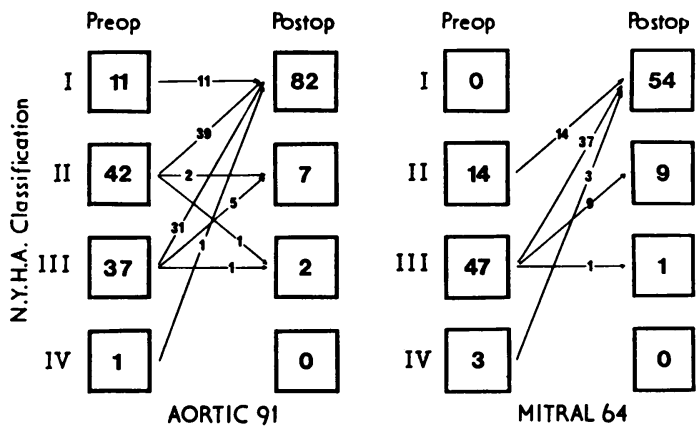

FIG. 6. Diagrammatic presentation of pre- and postoperative effort tolerance graded according to the New York Heart Association classification in 91 patients with aortic and 64 with mitral valve replacement followed up for 6 to 54 months postoperatively.

Electrocardiogram In patients with aortic valve replacement there was a statistically significant reduction $(\mathrm{P}<0.001)$ in the summation of voltage of $R$ in $V_{6}$ and $S$ in $V_{1}$ postoperatively. In patients with mitral or tricuspid valve replacement the electrocardiographic changes were not statistically significant.

Radiological changes There has been a variable decrease in the cardiothoracic ratio in most cases of aortic valve replacement. The mean reduction was statistically significant $(P<0.001)$ in all patients except those with isolated aortic valve stenosis preoperatively $(P>0 \cdot 2)$. When present, the reduction in cardiothoracic ratio took place mainly during the first six months after operation. In patients with mitral or tricuspid valve replacement the mean reduction in cardiothoracic ratio was not statistically significant.
Data concerning the clinical condition of patients with tricuspid valve replacement are presented in Table VIII.

Calcification of the tissue valves has not been noted in any of the patients during the follow-up period of 6 to 54 months postoperatively.

Haemodynamic studies Haemodynamic studies were performed six months following aortic valve replacement in 10 patients with competent grafts. There was no statistically significant change in cardiac output as compared with the preoperative values. The cardiac output response relative to oxygen uptake during exercise, however, was normal in the majority of cases. The pulmonary wedge pressure (PWP) showed a significant reduction at rest $(16 \pm 3 \mathrm{mmHg}$ to $10 \pm 1 \mathrm{mmHg}$; $\mathrm{P}<0.05)$ and during exercise $(31 \pm 6 \mathrm{mmHg}$ to $16 \pm 2 \mathrm{mmHg} ; \mathrm{P}<0.01)$. There was a slight reduction in the pulmonary artery pressure (PAP) at rest $(22 \pm 2 \mathrm{mmHg}$ to $18 \pm 1 \mathrm{mmHg} ; \mathrm{P}>0.3)$ and a significant reduction during exercise $(47 \pm 7 \mathrm{mmHg}$ to $28 \pm 3 \mathrm{mmHg} ; \mathrm{P}<0.001)$. However, some of the individual values, especially during exercise, remained elevated.

The peak systolic gradient across the aortic valve grafts ranged from 0 to $30 \mathrm{mmHg}$ (mean $12 \pm 3 \mathrm{mmHg}$ ) at rest and did not increase significantly during exercise (mean $14 \pm 3 \mathrm{mmHg}$ ). This could be explained by the fact that the obstruction to forward flow is not fixed, and during exercise, with the increase in cardiac output, there is further opening of the cusps which accommodates the additional flow without increasing the transvalvular gradient.

Haemodynamic studies following mitral valve replacement with fascia lata grafts were performed at six months and at a mean interval of 38 months after surgery, at rest and during exercise, in 10 patients with competent grafts. Cardiac output did not change significantly from the preoperative values during the postoperative studies, and cardiac output response in relation to the oxygen uptake during exercise remained impaired. The mean PWP and PAP showed a significant reduction during the first postoperative study, at rest (PWP from $24 \pm 2 \mathrm{mmHg}$ to $14 \pm 1 \mathrm{mmHg} ; \mathrm{P}<0.001$; and PAP from $35 \pm 3 \mathrm{mmHg}$ to $24 \pm 5 \mathrm{mmHg}$; $\mathbf{P}<0.001$ ) and during exercise (PWP from $47 \pm 3 \mathrm{mmHg}$ to $34 \pm 3 \mathrm{mmHg} ; \mathrm{P}<0.001$; and PAP from $66 \pm 5 \mathrm{mmHg}$ to $50 \pm 3 \mathrm{mmHg} ; \mathrm{P}<0.001$ ). During the second postoperative study there was a further significant decrease in the PWP and PAP at rest although some individual values still remained above normal limits and the normal response of these parameters to exercise, as 
Replacement of heart valves with frame-mounted tissue grafts

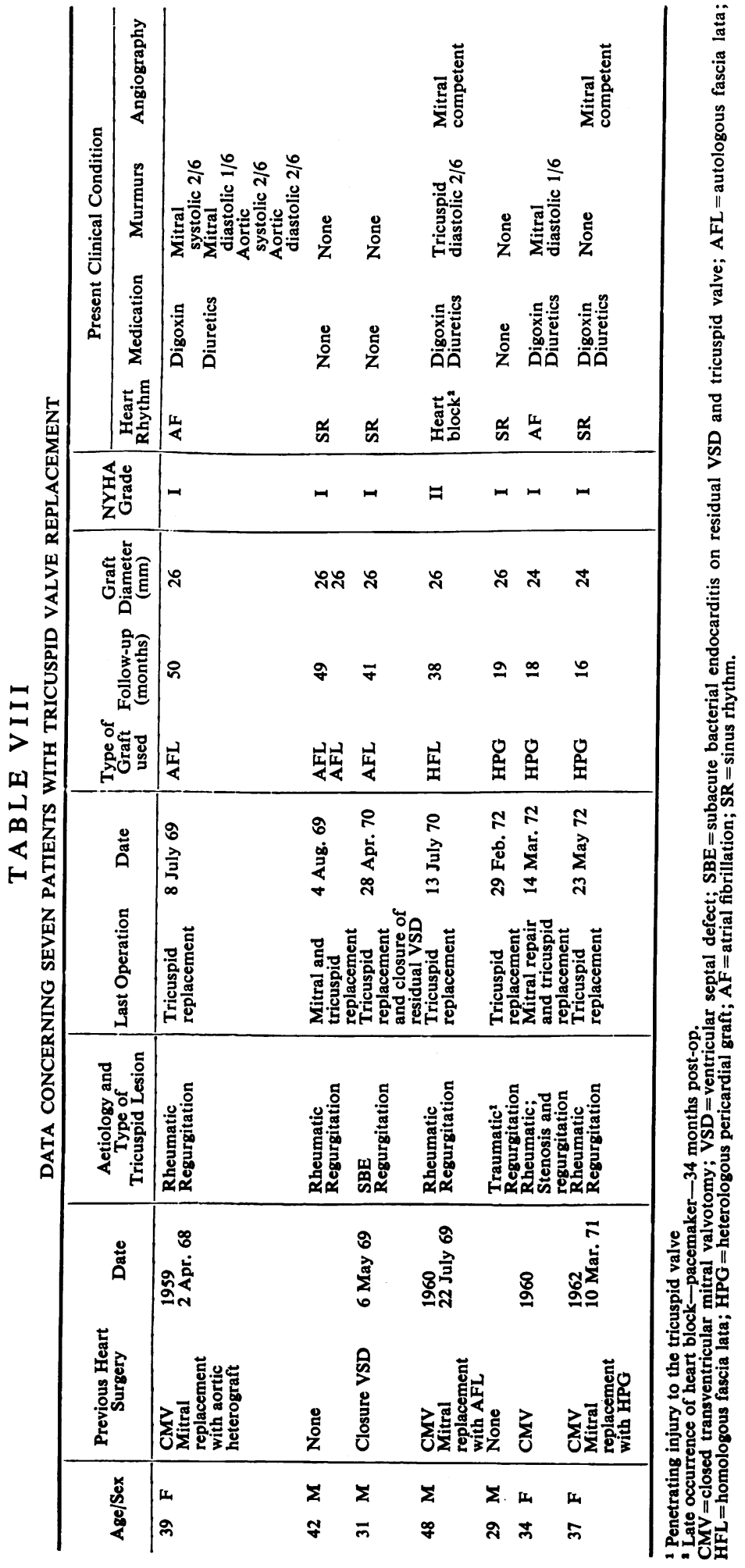

$\frac{\sqrt{3}}{\frac{\partial}{2}}$

$\stackrel{\overrightarrow{\mathrm{S}}}{\stackrel{9}{9}}$

음

$\frac{\overline{\mathrm{C}}}{\overline{\mathrm{D}}}$

क

$\vec{\circ}$

$\overrightarrow{\vec{\omega}}$

$\stackrel{\vec{x}}{\vec{x}}$

กู

घू

옥

$\vec{c}$

ปั

$\overrightarrow{0}$

$\stackrel{D}{A}$

동

方

ֻ

$\stackrel{8}{2}$

혹

阜

宰

을

훙.

ㅇํㄹ

오

을

N

N

w

$\stackrel{\circ}{\mathbb{D}}$

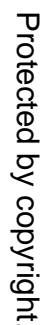


observed during the first study, remained unchanged. This could be attributed to obstruction to the forward flow at the mitral valve graft level as the left ventricular end-diastolic pressure was normal in most instances both at rest and during exercise. The end-diastolic gradient across the mitral valve graft was $6 \pm 1 \mathrm{mmHg}$ at rest and $20 \pm 4 \mathrm{mmHg}$ during exercise.

These data indicate that following mitral valve replacement there is a significant haemodynamic improvement in the early postoperative period and that this improvement is maintained at least up to three years after surgery. However, a degree of obstruction to the forward flow at the mitral valve is apparent, especially during exercise.

\section{DISCUSSION}

The results obtained over a period of four and a half years with our first 213 patients with framemounted fascia lata and pericardial grafts have shown a different pattern of valve graft function between the aortic and the mitral position.

The hospital mortality rate compares favourably with results obtained with other types of valve substitutes. At the beginning of this series coronary perfusion was not used, and this might have been responsible for three of the early deaths after aortic valve replacement. There was only one hospital death in the last 51 patients operated upon for aortic valve replacement.

Advanced preoperative heart disease and infective endocarditis were the main causes of late deaths in this series.

Since January 1971, the policy of preventing, detecting, and treating infections has been completely changed. The patients receive $1 \mathrm{~g}$ of ampicillin-cloxacillin six-hourly for $\mathbf{4 8}$ hours only, during and after the operation. Pre- and postoperative bacteriological and mycological screening is routinely performed, and the diagnosed infections are treated electively (Freeman, 1974). Since this policy was adopted there has been a continuous reduction in the incidence of infective endocarditis.

The most important factor in the evaluation of tissue grafts for heart valve replacement is the evidence of satisfactory graft function over extended periods of time.

It has been shown that preserved homologous aortic valves in the aortic position are associated with a significant incidence of aortic regurgitation. The reported incidence of aortic regurgitation after homograft replacement varies from $37.8 \%$ to $60 \%$ (Barratt-Boyes et al., 1969; Gonzalez-Lavin and
Ross, 1970; Beach and Malm, 1972; Trimble, 1972). A comparison of the incidence of regurgitant murmurs in aortic homografts with that encountered in the present series of fascial and pericardial grafts $(11.6 \%)$ is difficult because no really comparable data are available.

All the aortic diastolic murmurs in our series have appeared in the first eight months after surgery. Only two patients out of 40 with heterologous pericardial grafts have trivial aortic diastolic murmurs. The follow-up of this group of patients with pericardial grafts extends from 6 to 30 months, and 30 patients have a follow-up longer than 10 months.

In the mitral position there have been six instances of graft failure. In these patients the clinical deterioration was progressive but slow and the reoperation was performed as a scheduled procedure. In each of these six cases there was retraction and severe thickening of one cusp and slight to moderate thickening of the other two cusps of the autologous fascia lata valves. The fact that no relationship could be established between the circumferential position of the retracted cusp and the left ventricular outlet differs from the observations of McEnany, Ross, and Yates (1972) and Ross (1972). This finding supports the view that the flow pattern in the left ventricular outlet cannot be entirely responsible for valve graft failure.

Another observation was the fact that the degree of pathological changes was similar in all six failed grafts although the time of their removal varied widely from 10 to 38 months postoperatively.

Mitral systolic murmurs developed in 33 patients. None of them is presently in need of further surgical treatment. In 32 patients the murmur appeared during the first 12 postoperative months. In the majority of cases, the murmur has not increased in intensity and the clinical condition of the patients is good.

Although the number of patients with heterologous pericardial grafts in the mitral position is small and although the follow-up does not exceed 30 months, the absence of regurgitant murmurs in these cases is encouraging.

From the present series it became apparent that the same type of autologous fascial graft which has failed in six instances in the mitral position continues to function well in the aortic position up to four and a half years after implantation. It seems conceivable that biological factors alone cannot explain the failure phenomenon and that mechanical factors in valve graft construction and haemodynamic differences between the mitral and 
the aortic areas are equally if not principally responsible.

The long-term function of stented grafts in the tricuspid position cannot be assessed because of the very small number of patients (three with autologous and one with homologous fascia lata and three with heterologous pericardial valves) and owing to the differing periods of follow-up of these seven patients.

In order to understand the complex mechanism of function of frame-mounted tissue valves and in order to elucidate the causes of their different behaviour in the mitral as compared to the aortic position, hydrodynamic studies have been conducted in vitro using different valve testing machines.

The closing mechanism of three-cusp valves has been studied extensively (Bellhouse and Bellhouse, 1968). On the other hand, the opening mechanism of these valves, especially in the mitral position, has not received enough attention.

Using a steady-state flow rig and several pulse simulators, we have studied a large number of frame-mounted, three-cusp tissue valves (Swales et al., 1973). The conclusions of these investigations can be summarized as follows:

1. In virtually all valves examined the cusps opened in a sequential manner and the order in which the cusps of a particular valve opened was maintained irrespective of the circumferential position of the cusps as regards the left ventricular outlet in the testing apparatus.

2. Under the conditions prevailing in the experiment the sequential opening of the cusps seemed to be inherent to the design of the valve. Irregularities in the size and shape of the cusps or in the physical properties of the material accentuated this phenomenon.

3. Fully open valves were geometrically similar and the relationship between pressure gradient, flow rate, and valve diameter has the form: $\mathrm{pd}^{4}=4600 \mathrm{Q}^{2}$. This formula will apply to all such valves tested in water irrespective of material or size, provided that they are fully open.

4. The pressure gradient across the valve increases rapidly as the diameter of the valve is reduced, and with reduction in valve diameter complete valve opening can be achieved by a smaller flow rate.

5. It is postulated that in patients with postoperative low cardiac output, large grafts in the mitral position may not open fully, and consequently the cusp with little or no mobility may undergo structural changes leading to fibrosis with thickening or atrophy when the valve is made of 'living', biologically active tissue, such as fresh autologous fascia lata.

6. In order to avoid sequential opening, the three cusps of the valve must be absolutely identical in thickness, pliability, and shape.

7. The construction of a perfect frame-mounted, three-cusp tissue valve is a real technical challenge.

8. All the factors mentioned above are less important for aortic valve grafts because in the aortic area complete opening of every cusp of the valve is facilitated by the forceful left ventricular ejection.

The average aortic peak blood flow velocity as well as the force applied to the aortic valve to open are higher than in the mitral area. The maximum ejection time of blood in the aortic root is considerably shorter than the period of rapid inflow from the left atrium through the mitral valve. The size of an aortic valve graft is always smaller than the size of a mitral valve. For the same cardiac output, considering that structurally and geometrically both valves are the same, the aortic valve has to open more fully.

With increasing knowledge about the function of fascial and pericardial grafts, a series of modifications and improvement in design, material, and construction have been made over the years.

Data concerning the use of fascia in general surgery show that, after autologous heterotopic transplantation outside the cardiovascular system, fascia continues to survive, maintaining its structure and function unchanged even after long periods of time. The use of autologous fascia as a heart valve replacement seems to follow a different pattern. The viability of the transplanted fibroblasts is uncertain (Lincoln et al., 1971), and there is evidence that the stained nuclei visible on the surface and between the collagenous fibres of fascial grafts removed from the heart are invading, potentially active host cells (Silver and Trimble, 1972). In these circumstances attempts to maintain the viability of the graft become unnecessary.

The construction of the graft in the operating theatre during surgery, with a limited amount of time available, does not offer the best conditions for the preparation of a perfect valve.

For these two reasons, we have replaced the autologous fascia lata with homologous fascia. Preparation of the graft in the laboratory gives ample time to a skilled assistant to select the most suitable piece of tissue and to construct the valve meticulously and unhurriedly. It can be inspected, tested, and then retained for clinical use only if it fulfils the criteria mentioned.

Preserved heterologous pericardium was used 
later instead of fascia lata because it was considered that the thinness and pliability of the pericardium are more important qualities for good valve functioning than the greater tensile strength of fascia lata.

For sterilization and preservation of the valves made of heterologous pericardium we have used the method advocated by Carpentier and Dubost (1972). It seems to prevent immunological reactions by reducing the antigenic potential of the tissue, and it prevents denaturation of the collagen by creating permanent intermolecular crosslinkages. In these circumstances the durability of the valve graft does not depend upon regeneration by host cells of the tissue used but rather on the stability of the biological material.

One specimen of heterologous pericardium examined six months after insertion in the aortic position and another one examined 12 months after insertion in the right ventricular outlet have shown that the structure of the pericardium was preserved intact and that host cell ingrowth did not take place. Macroscopically and microscopically both these grafts were identical with valve grafts before clinical implantation.

Several changes in graft construction have evolved from the clinical and experimental experience. For the small-size aortic valves (16 to $20 \mathrm{~mm}$ diameter) the prongs of the supporting frame have been splayed, and thereby the outflow or secondary orifice of the graft has been increased to equal the inflow opening at the base of the frame.

In order to prevent the unpredictable change in valve cusp shape during surgical insertion, the suturing rim is attached to the support frame only after the tissue graft has been stitched to the frame. Changes in position of the suturing rim can no longer distort the geometry of the graft. All these technical improvements have contributed to an improvement in clinical results.

\section{CONCLUSIONS}

The results obtained over a period of four and a 흠 half years with the first 213 patients with frame- $\frac{\rho}{7}$ mounted fascia lata and pericardial valves have $\stackrel{\mathbb{\Omega}}{\Omega}$ shown differences between the function of the $\%$ grafts in the two main implantation positions, the $\vec{\circ}$ mitral and the aortic areas.

The experience with patients with aortic valve $\overrightarrow{\vec{\omega}}$ replacement has demonstrated an acceptable hospital and late mortality rate and good valve func- $\vec{x}$ tion with no graft failure up to four and a half years postoperatively. In this series, the incidence:of aortic regurgitation has been low when com-gr pared with that encountered after aortic homo-o graft valve replacement. Valves made of preserved ${ }^{3}$ heterologous pericardium have shown the loweste incidence of aortic diastolic murmurs.

The clinical results in patients with mitral valve replacement have been good although six grafts $₹$ had to be removed due to failure, and half the $\vec{\varphi}$ patients who left hospital have developed mitral $\not$ systolic murmurs.

However, long-term survivors with aortic as well as mitral tissue valve replacement have obtained considerable symptomatic improvement.

The incidence of thromboembolism has been $\frac{}{8}$ low although anticoagulants were not used.

In a small series of patients with tricuspid $\overline{\overrightarrow{0}}$ replacement the follow-up has shown very good valve function with no failure or dysfunction, no thromboembolic complications, and considerable clinical improvement (Table IX).

It is considered that if the physical properties conferred on the heterologous pericardium by the chemical treatment described are maintained and 3 . if host tissue ingrowth does not occur, the pericardial grafts should continue to function adequately for extended periods of time as heart valve replacement. There are some clinical and labora- -

T A B L E I X

BIOLOGICAL TISSUE HEART VALVE REPLACEMENT (213 PATIENTS) APRIL 1969-SEPTEMBER 1973

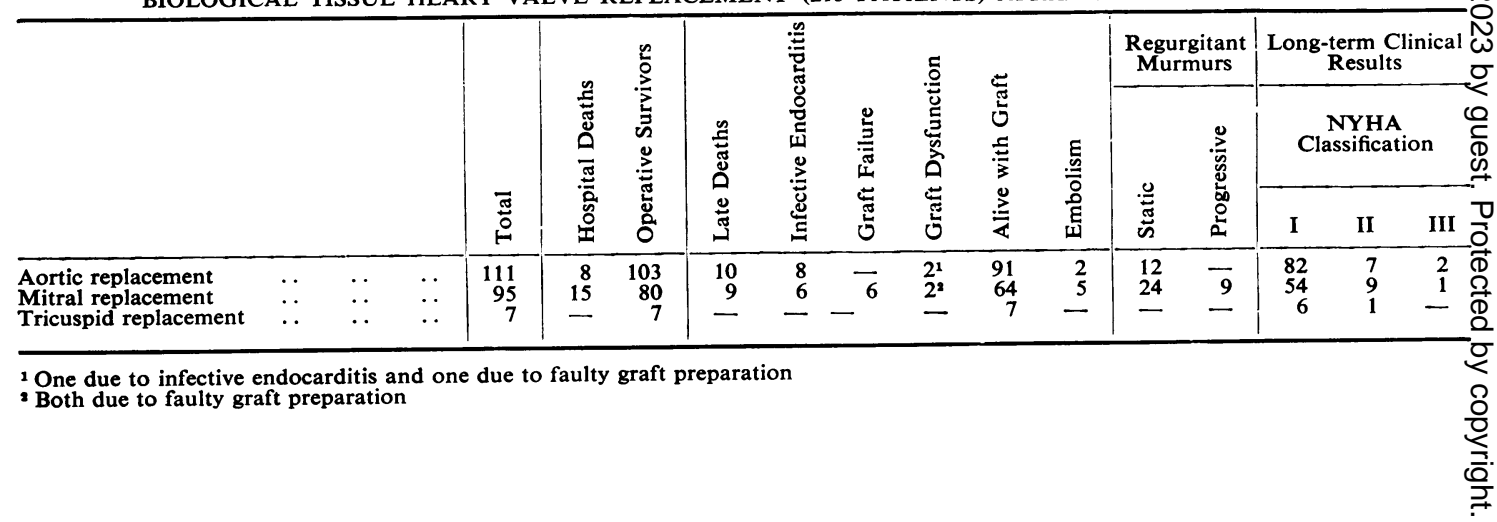


tory data which support the veracity of this presumption.

By means of improved techniques and materials for valve construction it is anticipated that postoperative valve regurgitation could be reduced and the long-term function of the grafts maintained. The construction of a perfect valve graft is crucial for its long-term function. The merits of this method of heart valve replacement will continue to be evaluated as the period of followup increases.

The authors wish to express their gratitude to Miss Beryl Walsh, Drs Roger Freeman and Said $M$. Fayoumi, Mr. Roger Catchpole, and Mrs. Julie Walsh for invaluable help with this work.

This study was supported by the British Heart Foundation.

\section{REFERENCES}

Barratt-Boyes, B. G., Roche, A. H. G., Brandt, P. W. T., Smith, J. C., and Lowe, J. B. (1969). Aortic homograft valve replacement: a long-term follow-up of an initial series of 101 patients. Circulation, 40, 763.

Bartek, I. T., Holden, M. P., and Ionescu, M. I. (1974). Frame-mounted tissue heart valves: technique of construction. Thorax, $29,51$.

Beach, P. M. Jr. and Malm, J. R. (1972). Homologous aortic valve replacement. In Biological Tissue in Heart Valve Replacement, edited by M. I. Ionescu, D. N. Ross, and G. H. Wooler, p. 313. Butterworths, London.

Bellhouse, B. J." and Bellhouse, F. H. (1968). Mechanism of closure of the aortic valve. Nature, 217, 86.

Brandt, P. W. T., Roche, A. H. G., Barratt-Boyes, B. G., and Lowe, J. B. (1969). Radiology of homograft aortic valves. Thorax, 24, 129.

Carpentier, A. and Dubost, C. (1972). From xenograft to bioprosthesis: evolution of concepts and techniques of valvular xenografts. In Biological Tissue in Heart Valve Replacement (edited by M. I. Ionescu, D. N. Ross, and G. H. Wooler) p. 515. Butterworths, London.

Dave, K. S., Madan, C. K., Pakrashi, B. C., Roberts, B. E., and Ionescu, M. I. (1972). Chronic hemolysis following fascia lata and Starr-Edwards aortic valve replacement. Circulation, 46, 240.

Freeman, R. (1974). Microbiological aspects of open-heart surgery: diagnosis and management. In Current Techniques in Extracorporeal Circulation, edited by M. I. Ionescu and G. H. Wooler. Butterworths, London. and King, B. (1972a). Technique for the performance of the nitro-blue tetrazolium (N.B.T.) test. Journal of Clinical Pathology, 25, 912.

(1972b). Infective complications of indwelling intravenous catheters and the monitoring of infections by the nitroblue-tetrazolium test. Lancet, 1, 992.

Gonzalez-Lavin, L. and Ross, D. N. (1970). Homograft aortic valve replacement: a five-year experience at the National Heart Hospital, London. Journal of Thoracic and Cardiovascular Surgery, 60, 1.

Ionescu, M. I., Deac, R. C., Whitaker, W., Wooler, G. H., Holden, M. P., and Petrila, P. A. (1972). Fascia lata heart valves. In Biological Tissue in Heart Valve Replacement, edited by M. I. Ionescu, D. N. Ross, and G. H. Wooler, p. 617. Butterworths, London.

- and Ross, D. N. (1969). Heart-valve replacement with autologous fascia lata. Lancet, 2, 335.

—, _- Deac, R. C., and Wooler, G. H. (1970a). Heartvalve replacement with autologous fascia lata. Journal of Thoracic and Cardiovascular Surgery, 60, 331.

- - - Wooler, G. H., Deac, R. C., and Ray, D. (1970b). Replacement of heart valves with autologous fascia lata: surgical technique. British Journal of Surgery, 57, 437.

Lincoln, J. C. R., Riley, P. A., Revignas, A., Geens, M., Ross, D. N., and Ross, J. K. (1971). Viability of autologous fascia lata in heart valve replacements. Thorax, 26, 277.

McEnany, M. T., Ross, D. N., and Yates, A. K. (1972). Cusp degeneration in frame-supported autologous fascia lata mitral valves. Thorax, 27, 23.

Moeys, E. J., Mreyen, F. W., and den Hartog, B. J. C. (1954). Homotransplantation of formaldehyde-preserved arteries in dogs. Archivum Chirurgicum Neerlandicum, 6, 333.

Reis, R. L., Hancock, W. D., Yarbrough, J. W., Glancy, D. L., and Morrow, A. G. (1971). The flexible stent: a new concept in the fabrication of tissue heart valve prostheses. Journal of Thoracic and Cardiovascular Surgery, 62, 683.

Ross, D. N. (1972). Biologic valves, their performance and prospects. Circulation, 45, 1259.

Silver, M. D. and Trimble, A. S. (1972). Structure of autologous fascia lata heart valve prostheses. Archives of Pathology, 93, 109.

Swales, P. D., Holden, M. P., Dowson, D., and Ionescu, M. I. (1973). Opening characteristics of three-cusp tissue heart valves. Thorax, 28, 286.

Trimble, A. S. (1972). Late results of aortic valve replacement-a clinical and haemodynamic evaluation. In Biological Tissue in Heart Valve Replacement, edited by M. I. Ionescu, D. N. Ross, and G. H. Wooler, p. 349. Butterworths, London. 